\title{
Airport malaria: report of four cases in Tunisia
}

\author{
Emna Siala ${ }^{1,2^{*}}$, Dhikrayet Gamara ${ }^{3}$, Kalthoum Kallel $^{4}$, Jabeur Daaboub ${ }^{5}$, Faiçal Zouiten ${ }^{6}$, Sandrine Houzé ${ }^{7}$ \\ Aïda Bouratbine ${ }^{1,2}$ and Karim Aoun ${ }^{1,2}$
}

\begin{abstract}
Four cases of airport malaria were notified for the first time in Tunisia during the summer of 2013. All patients were neighbours living within $2 \mathrm{~km}$ of Tunis International Airport. They had no history of travel to malarious countries, of blood transfusion or of intravenous drug use. Although malaria transmission had ceased in Tunisia since 1980, autochthonous infection by local Anopheles mosquitoes was initially considered. However, this diagnostic hypothesis was ruled out due to negative entomological survey and the absence of additional cases.

All cases were caused by Plasmodium falciparum. Clinical presentation was severe (important thrombocytopaenia and parasitaemia), because of relatively important delay in diagnosis (average of seven days). This indicates the need to consider malaria while examining airport employees or people living near international airports presenting with fever of unknown origin. It also stresses the need for effective spraying of aircrafts coming from malarious areas.
\end{abstract}

Keywords: Airport malaria, Plasmodium falciparum, Anopheles, Tunisia

\section{Background}

Malaria has been eliminated from Tunisia in 1979 [1]. Since then, no local cases have been notified. Recently, between 50 and 75 cases of imported malaria are registered yearly [2], mainly in travellers and migrants coming from malarious countries [3]. The present report refers to four local airport malaria cases in Tunisian citizens who had never been to endemic areas.

\section{Case reports}

Case 1

A 27-year-old man presented on 3 July 2013 with fever $\left(40^{\circ} \mathrm{C}\right)$, myalgia and headache of two days standing for which he received paracetamol without improvement. The biological assessment showed WBC at $4,230 / \mathrm{mm}^{3}$, haemoglobin at $16 \mathrm{~g} / \mathrm{dL}$ and thrombocytopaenia $\left(85,000 / \mathrm{mm}^{3}\right)$. Antibiotic therapy was prescribed. On 11 July, because of the persistence of fever, a second biological assessment was required and showed a thrombocytopaenia at $35,000 / \mathrm{mm}^{3}$. Blood smear performed to control thrombocytopaenia and check the presence of aggregated platelets revealed intra-erythrocytic

\footnotetext{
* Correspondence: emnasiala99@gmail.com

'Laboratoire de Parasitologie-Mycologie, Tunis, Tunisia

${ }^{2}$ LR 11-IPT-06 «Parasitologie Médicale, Biotechnologies \& Biomolécules», Institut Pasteur de Tunis, Tunis, Tunisia

Full list of author information is available at the end of the article
}

trophozoites of Plasmodium falciparum with a parasitaemia at $1 \%$. The patient was treated with Lumartem ${ }^{\circ}$ (20 $\mathrm{mg}$ artemether/120 mg lumefantrine)(Cipla, India). $\mathrm{He}$ received a total of six doses (4 tablets per dose) over a period of three days, as recommended. The patient is a student, living within $2 \mathrm{~km}$ of Tunis international airport.

\section{Case 2}

A 25-year-old friend and neighbour of case 1 presented on 6 July 2013 to the emergency department with fever, headache and myalgia accompanied by epistaxis. The diagnosis of angina was accepted and the patient was treated with amoxycillin. On the next day, the patient's general condition deteriorated with vomiting, fever, and shivering. Laboratory investigations revealed leukocytopaenia at $2,300 / \mathrm{mm}^{3}$ with thrombocytopaenia $\left(26,000 / \mathrm{mm}^{3}\right)$ and abnormal liver function findings (ALAT 124UI/L, ASAT 129UI/L). Serological tests for influenza A and $B$ virus were positive and Tamiflu was prescribed. On 11 July, malaria was suspected based on the diagnosis of case 1, and microscopic examination of blood smears confirmed the presence of $P$. falciparum with parasitaemia at $12 \%$. The patient was treated for seven days with intravenous quinine dihydrochloride ${ }^{\bullet}$ (Rotexmedica, Germany) $8 \mathrm{mg} / \mathrm{kg}$ quinine base every eight hours after an initial loading dose of $17 \mathrm{mg} / \mathrm{kg}$. 


\section{Case 3}

A 21-year-old man, living within $200 \mathrm{~m}$ from cases 1 and 2 was admitted to a private clinic with vomiting, shivering and muscular pain of one week's standing. He had received paracetamol and metoclopramide (Primperan ${ }^{\circ}$ ). On 13 July, laboratory tests revealed thrombocytopaenia $\left(26,000 / \mathrm{mm}^{3}\right)$, leukocytes $4,600 / \mathrm{mm}^{3}$, $\mathrm{C}$ reactive protein at $163 \mathrm{mg} / \mathrm{l}$, and abnormal liver function transaminase (ALAT 79UI/L, ASAT 50UI/L). In light of the two recent cases diagnosed in the same area, malaria was rapidly suspected and a microscopic examination of blood smears confirmed the presence of P. falciparum with a $0.5 \%$ parasitaemia level. The patient was treated with Lumartem.

\section{Case 4}

A 21-year-old man presented on 7 July with fever, myalgia, shivering and vomiting that had begun two days earlier and persisted despite treatment with paracetamol. Oral antibiotic therapy (amoxicillin/clavulanate) was prescribed. After an initial improvement, the patient's symptoms recurred with pain in the right hypochondrium. Consequently, he was admitted to hospital on 12 July, where physical examination revealed a slight spleen enlargement. Laboratory findings showed thrombocytopaenia at $38,000 / \mathrm{mm}^{3}$, leukocytopaenia at $3,800 / \mathrm{mm}^{3}, \mathrm{C}$ reactive protein at $220 \mathrm{mg} / \mathrm{l}$ and slightly elevated liver enzymes (ALAT 68UI/L, ASAT 62UI/L). Microscopic examination of blood smears was prescribed and revealed P. falciparum (parasitaemia $=0.01 \%$ ). The patient was treated with Lumartem ${ }^{\oplus}$.

History taking revealed that all cases lived in the same residential area within a radius of $2 \mathrm{~km}$, south east of Tunis Carthage International Airport. They had no history of travel to malaria endemic areas or of blood transfusion. Repeated interviews eliminated also intravenous drug use. Three of the four patients were close friends. PCR testing confirmed P. falciparum in all cases. The genomic characterization of isolates was performed in the Malaria National Reference Centre Paris, France. It was performed on DNA extracted from blood samples by using the QIAamp DNA Blood kit (Qiagen, Germany) according to the manufacturer's recommendations. Five P. falciparum microsatellite loci (TAA 81, TAA 87, TAA 60, PKPK 1, and ARA 2) located on different chromosomes were genotyped using the method described by Musset et al. [4]. Genotyping showed similar plasmodial strains of P. falciparum in all extracts. Treatment led to rapid improvement in all cases and recovery was confirmed by negative control blood smears (Days 7, 14 and 28). As soon as the $1^{\text {st }}$ patient was diagnosed, active screening of febrile individuals living in the area (Berges du lac) was carried out for several months without detecting new cases of malaria.

\section{Mosquito investigation}

An entomological survey was conducted in July 2013 during four days in the patients' neighbourhood. Adult mosquitoes were caught using CDC light traps and larval stages were collected in available water collections. No Anopheles specimens were captured.

\section{Discussion}

The four airport malaria cases diagnosed in Tunisia during the summer of 2013 concerned citizens born after the stop of Plasmodium parasite transmission. All patients had never travelled to malaria endemic areas and had no history of blood transfusion. The hypothesis of infection through intravenous drug use was also ruled out by careful history taking. Although eliminated from Tunisia since 1980, infection by local mosquito bites was initially considered as it had previously occurred in Algeria, Greece, Italy and United States [5-8]. In fact, a resurgence of the disease cannot be totally excluded because of the coexistence in Tunisia of imported malaria cases acting as a potential reservoir and local Anopheles representing potential vectors $[9,10]$. However, the entomological investigations carried out rapidly around the patient's homes did not detect any anopheline insect. Moreover, the absence of additional cases in spite of active screening of the susceptible population ruled out the possibility of autochthonous transmission by local mosquitoes.

All four patients were geographically located in the same restricted district just $2 \mathrm{~km}$ distant from Tunis International Airport. Onset of symptoms occurred in a short period of less than one week. By ruling out infection by local mosquitoes, exchange of contaminated needles and blood transfusion, it was concluded that the transmission occurred through the bites of infected Anopheles mosquitoes transported by aircraft from a malaria endemic country. In fact, Tunis international airport is linked by regular flights to many West-African capitals where malaria transmission is common such as Abidjan, Bamako, Dakar, Nouakchott and Ouagadougou. Moreover, the local conditions, especially the temperatures in June 2013; corresponding to the supposed period of contamination (mean $23^{\circ} 7 \mathrm{C}$, range: $17^{\circ} 2$ to $31^{\circ} 1 \mathrm{C}$ ), were auspicious for the survival and the activity of imported mosquito vectors [11].

Airport malaria is not an exceptional event. Between 1969 and 1999, 89 cases were reported in Europe mainly in France, Belgium, Italy, the Netherlands, Spain, Switzerland and UK [12-15]. Most infected patients lived near or worked in an international airport. Airport malaria occurred mainly in summer from June to September, when climatic conditions are favourable to mosquitoes [11]. The infected female mosquito leaving the aircraft, can survive long enough and can be dispersed under wind 
conditions from 7 to $15 \mathrm{~km}[16,17]$. It could be transported further by vehicle and baggage $[18,19]$.

Genotyping of the four P. falciparum isolates obtained from patients showed that a similar strain was involved. This finding could suggest several infections caused by the same mosquito taking an interrupted blood meal. Although rare, such event had been previously reported in 1999 with three malaria cases induced [20]. Bites by distinct anopheline females coming from the same malaria focus and infected by the same clone cannot be totally excluded.

Malaria is generally unsuspected by clinicians in patients from non-endemic countries who have never travelled to malarious areas. Hence, all four cases were diagnosed relatively late. Because of this delay (average of 7 days), $P$. falciparum aetiology and the naive immune status of the patients, the observed clinical and biological presentations were severe (deep thrombocytopaenia, high parasitaemia). Therefore, malaria should be considered in case of high fever of unknown origin particularly in airport employees or people living near international airports.

Beyond the possibility of airport malaria cases, new direct flights between Tunisia and some sub-Saharan African countries increases the risk of invasion by highly competent vectors, as has happened with Anopheles gambiae in Brazil and Egypt $[21,22]$. This can lead to resurgence of malaria transmission [23]. Preventive recommendations, such as aircraft spraying should be followed strictly [24]. All potential larvae habitat in and around international airports and ports should also be eliminated or disinfected.

\section{Conclusion}

The occurrence of airport malaria in Tunisia stresses the need for sensitization of clinicians for considering malaria in febrile individuals even when they have not travelled to an endemic area. Beside, this report highlights the importance of efficient disinfection of aircraft arriving from endemic areas.

\section{Consent}

Written informed consent was obtained from the patient for publication of this Case report. A copy of the written consent is available for review by the Editor-in-Chief of this journal.

\section{Competing interests}

The authors declare that they have no competing interests.

\section{Authors' contributions}

ES was involved in the biological diagnosis of cases and has written the manuscript. DG lead the epidemiological survey. KK contributed to the diagnosis of cases. JD conducted the entomological survey. FZ took part in the management of the patients. SH performed the isolates genotyping. $A B$ revised the manuscript. KA coordinated the investigation and revised the manuscript. All authors read and approved the final manuscript.

\section{Acknowledgments}

We thank Ahmed Tabbabi, Adel Rhaiem and Mohamed Belkahla for participating to the epidemiologic investigation and Dr Neyla Ben Romdhane and Dr Mondher Gastli for diagnosis and management of the patients.

\section{Author details}

${ }^{1}$ Laboratoire de Parasitologie-Mycologie, Tunis, Tunisia. ${ }^{2}$ LR 11-IPT-06 «Parasitologie Médicale, Biotechnologies \& Biomolécules», Institut Pasteur de Tunis, Tunis, Tunisia. ${ }^{3}$ Direction des Soins de Santé de Base, Tunis, Tunisia. ${ }^{4}$ Laboratoire de Parasitologie-Mycologie, Hôpital La Rabta, Tunis, Tunisia. ${ }^{5}$ Direction de l'Hygiène du Milieu et de Protection de l'Environnement, Tunis, Tunisia. ${ }^{6}$ Consultation privée d'infectiologie, Tunis, Tunisia. ${ }^{7}$ Malaria National Reference Centre, AP-HP, Bichât Hospital, Paris, France.

Received: 7 November 2014 Accepted: 15 January 2015 Published online: 28 January 2015

\section{References}

1. Chadli A, Kennoun MF, Kooli J. Malaria in Tunisia: history and present status. Bull Soc Path Exot. 1985;78:844-51.

2. Anonymous. Epidemiological Bulletin Officer of Primary Health Care Direction: 1980-2007. Tunisia: Ministry of Health; 2008.

3. Bourabine A, Chahed MK, Aoun K, Krida G, Ayari S, Ben Ismail R. Imported malaria in Tunisia. Bull Soc Path Exot. 1998;3:203-7.

4. Musset L, Le Bras J, Clain J. Parallel evolution of adaptive mutations in Plasmodium falciparum mitochondrial DNA during atovaquone-proguanil treatment. Mol Biol Evol. 2007;24:1582-5.

5. Hammadi D, Boubidi SC, Chaib SE, Saber A, Khechache Y, Gasmi M. Malaria in Algerian Sahara. Bull Soc Path Exot. 2009;102:185-92.

6. Danis K, Baka A, Lenglet A, Van Bortel W, Terzaki I, Tseroni M, et al. Autochthonous Plasmodium vivax malaria in Greece. Euro Surveill. 2011;16:19993.

7. Romi R, Boccolini D, Menegon M, Rezza G. Probable autochthonous introduced malaria cases in Italy in 2009-2011 and the risk of local vector-borne transmission. Euro Surveill. 2012;17:20325.

8. Zucker JR. Changing patterns of autochthonous malaria transmission in the United States: a review of recent outbreaks. Emerg Infect Dis. 1996;2:37-43.

9. Chahed MK, Bouratbine A, Krida G, Ben Hamida A. Receptivity to malaria after eradication: current situation in Tunisia. Bull Soc Path Exot. 2001;94:271-6.

10. Aoun K, Siala E, Tchibkere D, Ben Abdallah R, Zallaga N, Chahed MK, et al. Imported malaria in Tunisia and its consequences on the resurgence of the disease. Med Trop (Mars). 2010;70:33-7.

11. Highton RB, Van Someren ECC. The transportation of mosquitoes between international airports. Bull World Health Organ. 1970;42:334-5.

12. Thang HD, Elsas RM, Veenstra J. Airport malaria: report of a case and a brief review of the literature. Neth J Med. 2002;60:441-3.

13. Van Den Ende J, Lynen L, Elsen P, Colebunders R, Demey H, Depraetere K, et al. A cluster of airport malaria in Belgium in 1995. Acta Clin Belg. 1998;53:259-63.

14. Majori G, Gradoni L, Gianzi FP, Carboni P, Cioppi A, Aureli G. Two imported malaria cases from Switzerland. Tropl Med Parasitol. 1990;41:439-40.

15. Rodger AJ, Cooke GS, Ord R, Sutherland CJ, Pasvol G. Cluster of falciparum malaria cases in UK airport. Emerg Infect Dis. 2008;14:1284-6.

16. Isaäcson M. Airport malaria: a review. Bull World Health Organ. 1989;67:737-43

17. Whitfield D. Two cases of falciparum malaria acquired in Britain. BMJ. 1984;289:1607-9.

18. Guillet P, Germain MC, Giacomini T, Chandre F, Akogbeto M, Faye O, et al. Origin and prevention of airport malaria in France. Trop Med Int Health. 1998;3:700-5.

19. Castelli F, Cabona MG, Brunori A, Carosi G. Imported mosquito: an uninvited guest. Am J Trop Med Hyg. 1994;50:548-9.

20. Jafari S, Durand R, Lusina D, Le Bras J. Molecular characterisation of airport malaria: four cases in France during summer 1999. Parasite. 2000;9:187-91.

21. Killeen GF, Fillinger U, Kiche I, Gouagna LC, Knols BG. Eradication of Anopheles gambiae from Brazil: lessons for malaria control in Africa? Lancet Infect Dis. 2002;2:618-27. 
22. Mikhail MW, Al-Bursheed KM, Abd El-Halim AS, Morsy TA. Studies on mosquito borne diseases in Egypt and Qatar. J Egypt Soc Parasitol. 2009;39:745-56.

23. Karch S, Dellile MF, Guillet P, Mouchet J. African malaria vectors in European aircraft. Lancet. 2001;357:235.

24. Gratz N, Steffen R, Cocksedge W. Why aircraft disinfection? Bull World Health Organ. 2000;78:995-1004.

Submit your next manuscript to BioMed Central and take full advantage of:

- Convenient online submission

- Thorough peer review

- No space constraints or color figure charges

- Immediate publication on acceptance

- Inclusion in PubMed, CAS, Scopus and Google Scholar

- Research which is freely available for redistribution 